\title{
Review
}

\section{MR Image-guided Focused Ultrasound Surgery}

\author{
KOJI MIKAMI ${ }^{1,2}$, TAKAMICHI MURAKAMI ${ }^{1}$, ATSUYA OKADA ${ }^{2}$, \\ TARO MARUKAWA ${ }^{2}$, HIRONOBU NAKAMURA ${ }^{1}$
}

\author{
${ }^{1}$ Department of Diagnostic and Interventional Radiology, Osaka University Graduate School of Medicine \\ ${ }^{2}$ Department of Diagnostic and Interventional Radiology, Iseikai Hospital
}

\begin{abstract}
Focused ultrasound surgery (FUS) is a completely noninvasive, focal thermal ablation method. Various clinical applications of ultrasound-guided FUS have been investigated over the last five decades. However, three inherent challenges limited the clinical efficacy of FUS until recently: imprecise localization, inability to monitor temperature elevation at the focal point, and difficulty evaluating the procedure's success during or immediately after treatment. Recent advances in magnetic resonance (MR) imaging have resolved these problems. Pretreatment MR images enable precise target definition and treatment planning. Temperature-sensitive phase-difference MR imaging can monitor the focal point and measure tissue temperature elevation in real time, ensuring delivery of a therapeutic dose. Posttreatment gadolinium-enhanced MR images provide immediate assessment of the treatment's success. In this article we review the principles, therapeutic methods, and clinical applications of MR image-guided FUS.
\end{abstract}

Key words: focused ultrasound, MR imaging

\section{Introduction}

In recent years, image guided tumor ablation techniques such as microwave therapy (MCT), radiofrequency ablation (RFA), laser-induced thermotherapy (LITT), and cryotherapy have been performed, and their effectiveness has been reported in the literature ${ }^{1-4)}$. However, these techniques all require percutaneous probe insertion to deliver thermal energy into the tumor. Focused ultrasound surgery (FUS) is an alternative thermal ablation method. Ultrasound is a form of vibrational energy that propagates a mechanical wave within a medium via molecular motion. Due to their short wavelength $(1.5 \mathrm{~mm}$ at $1 \mathrm{MHz})$, ultrasound beams can be focused with radiators, lenses, or reflectors ${ }^{5)}$ to accurately target well-defined sites, and produce localized high temperatures, without the need to insert a probe. This localized heating causes well-defined areas of coagulative necrosis, while sparing overlaying and surrounding tissues, making FUS an extremely noninvasive thermal ablation technique.

Lynn, et al. first investigated the effectiveness of focused ultrasound in 19425). Since then, focused

Received 28 March 2005, Accepted 13 April 2005. *Corresponding author, Tel : +81-6-6879-3434; Fax : +81-6-6879-3439;

E-mail : murakami@radiol.med.osaka-u.ac.jp 
ultrasound has been used therapeutically in several organs ${ }^{677}$. For example, the clinical effectiveness of focused ultrasound therapy under ultrasound guidance for prostate tumors has been reported ${ }^{899}$. However ultrasound images do not allow precise target definition, accurate focal spot control, or measurement of temperature elevation in the treated tissue ${ }^{7-10)}$. As a solution to these problems, magnetic resonance (MR) imaging has been used to guide and control FUS beginning in the $1990 \mathrm{~s}^{11-14)}$. MR imaging provides high sensitivity for localizing tumors, excellent anatomic resolution for precise targeting, and temperature sensitivity for measuring temperature elevation in treated tissue. The technical feasibility of performing FUS with MR imaging to guide and monitor therapy has been established in both animal experiments and clinical trials ${ }^{15-19}$. We review the principles, therapeutic methods, and clinical applications for MR image-guided FUS.

\section{MR Imaging-Compatible Focused Ultrasound System}

The MR image-guided FUS procedures described in this report were performed with the ExAblate 2000 (InSightec, Haifa, Israel) integrated into a Signa $1.5 \mathrm{~T}$ standard whole-body MRI system (GE Healthcare, Milwaukee WI, US) (Fig. 1). ExAblate is based on an earlier research system, which was produced by General Electric Healthcare in collaboration with personnel from the Brigham and Women' $s$ Hospital ${ }^{14)}$. ExAblate incorporates improvements in transducer design, real time MR thermometry feedback, and volumetric planning. A focused piezoelectric transducer array with 120-mm diameter and operating frequency between 1.0 and $1.5 \mathrm{MHz}$ generates the ultrasound field. The array is located in a water tank that is integrated into the MR imaging table. The array directs electronically controlled ultrasound signals to the target, and thus determines the coagulated tissue volume. Lateral motion of the transducer is achieved with a mechanical positioning device. A thin plastic membrane window covers the water tank and allows the ultrasound beam to propagate into the patient's body.

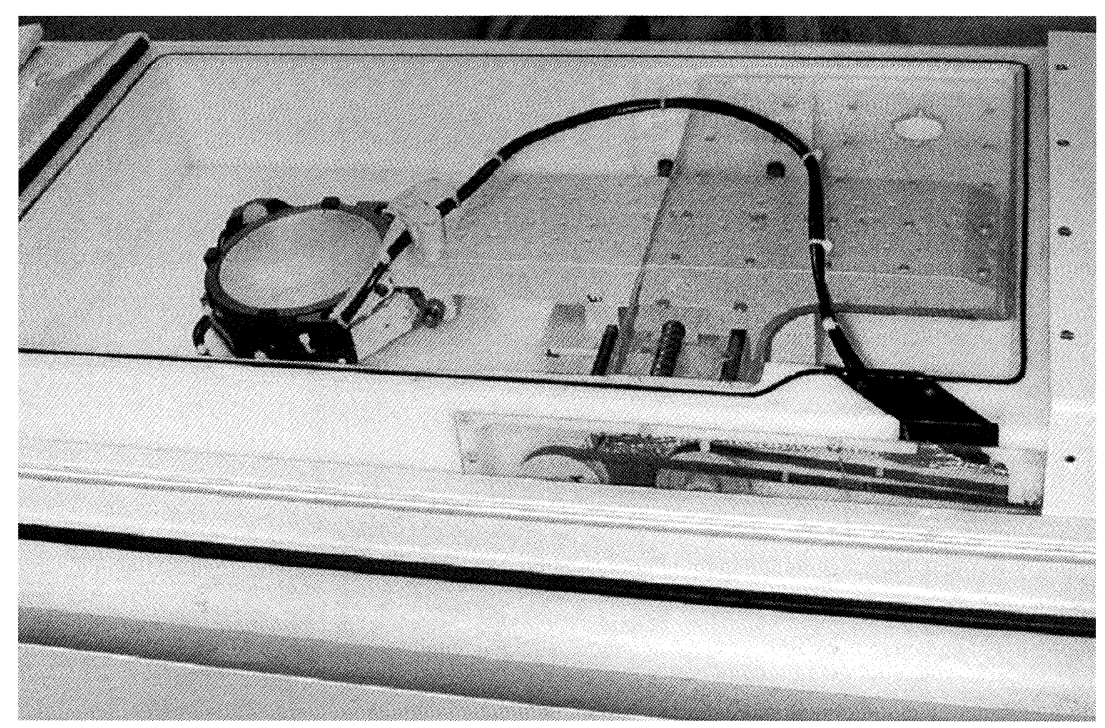

Fig. 1. ExAblate 2000 System

The transducer (arrow) is located in a water tank that is integrated into the MR imaging table. 


\section{Therapeutic Method}

\section{Pretreatment MR Imaging to Assess Indications for FUS and Plan Treatment}

Sagittal, coronal, and transverse T1-weighted gadolinium-enhanced spin-echo (SE) MR images, T2-weighted fast SE images, and dynamic gadolinium-enhanced spoiled gradient-recalled-echo MR images are used to locate the lesion, measure it, and define the target volume. Generally T2-weighted or gadolinium enhanced T1-weighted SE images are used for treatment planning. The target volume within the tumor is outlined, on coronal MR images using system software. The target volume is then visualized in two imaging planes, usually coronal and sagittal. System software displays the ultrasound beam overlaid on all tissue in its path. The beam can be repositioned or even tilted to optimize the path when needed.

\section{Temperature Monitoring with MR Imaging}

MR imaging with a fast spoiled gradient-recalled-echo sequence is performed to estimate the temperature dependent proton resonance frequency shift at the target ${ }^{20) 21}$. MR images provide real-time verification of the temperature in the target, enabling user control of both the magnitude and time course of tissue heating during treatment (Fig. 2A). Temperature dependence of the proton reasonance frequency has been shown to be linear above the coagulation threshold (Fig. 2B). To judge the adequacy of treatment, MR imaging-derived temperature information is analyzed and the temperature/ time history for each image voxel is calculated automatically by the system. The peak temperature and thermal dose derived from the MR images are used as a guide to ensure that adequate power is delivered to coagulate the target tissue. The treatment power level is set only after an initial, very low power localization pulse verifies the beam is focused on the target. Once treatment begins, the power is kept constant at each sonication level unless MR thermometry indicates that temperatures were below

$\mathbf{A}$

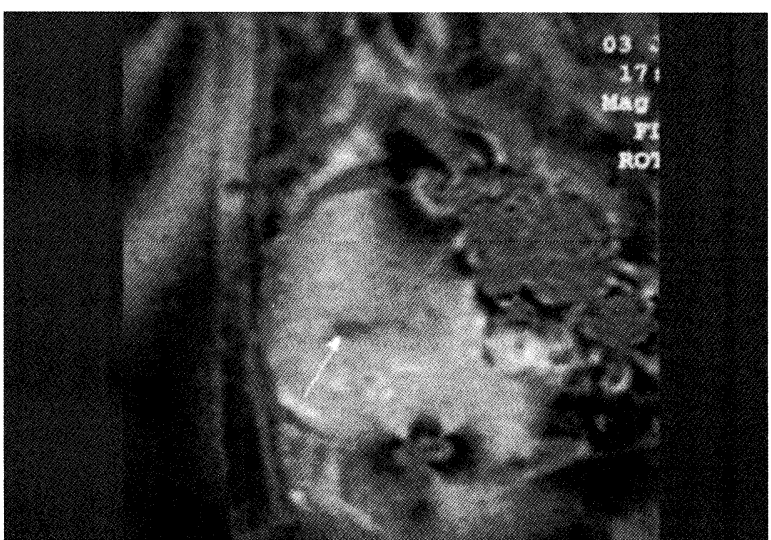

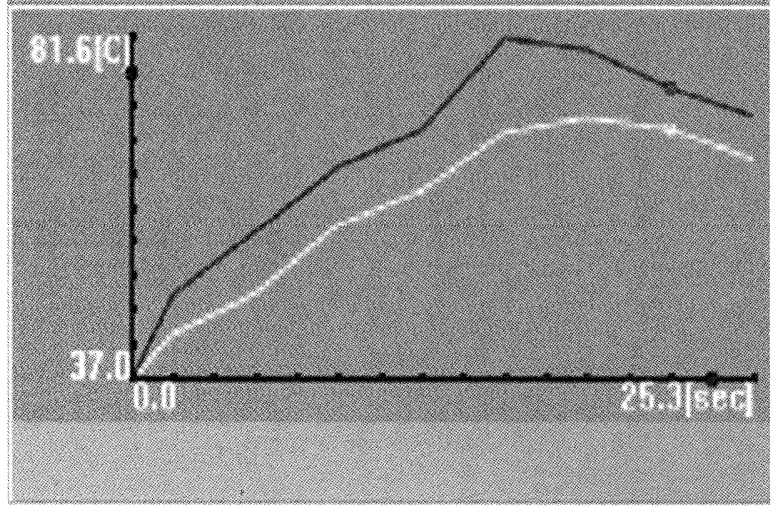

Fig. 2A. Temperature-sensitive phase-difference fast spoiled gradient-recalled-echo MR image

An area of low signal intensity (arrow) due to rise in temperature is visible at $22 \mathrm{sec}$ after onset of sonication in this sagittal image of a uterine leiomyoma. The area has been heated sufficiently to cause irreversible damage.

Fig. 2B. Graph of temperature against sonication time

White curve (arrow) represents average temperature within target volume. 
therapeutic levels, or that the thermal dose coverage was insufficient. In the latter case, the power was increased for all the remaining sonications to reach a threshold temperature without approaching higher temperatures at which control of the thermal effect may be compromised.

\section{Monitoring Treatment Effectiveness with MR Imaging}

After completion of treatment, and following intravenous injection of gadopentetate dimeglumine (Omniscan, Daiichi Pharmaceutical, Tokyo, Japan), multiphase fat-suppressed T1-weighted spoiled gradient-recalled-echo MR images are acquired to measure the nonperfused area within the tumor. Nonenhancing areas on gadolinium enhanced MR images obtained following FUS have been pathologically confirmed as areas of coagulative necrosis ${ }^{2223)}$.

\section{Clinical Applications}

\section{Treatment of Breast Tumor}

The feasibility of MR imaging-guided FUS surgery for breast tumor has been reported in the literature ${ }^{1516)}$. Hynynen, et al. reported partial or complete tumor ablation in eight of eleven patients with benign fibroadenomas ${ }^{15}$. However, almost complete ablation is needed for treatment of malignant breast tumors. Gianfelice, et al. reported their initial experience with MR image-guided FUS for invasive breast carcinomas in 12 patients $^{16)}$. In the last nine patients treated with the FUS system, which by then incorporated a multiple element phased array transducer with capability to treat lesions up to 20

A

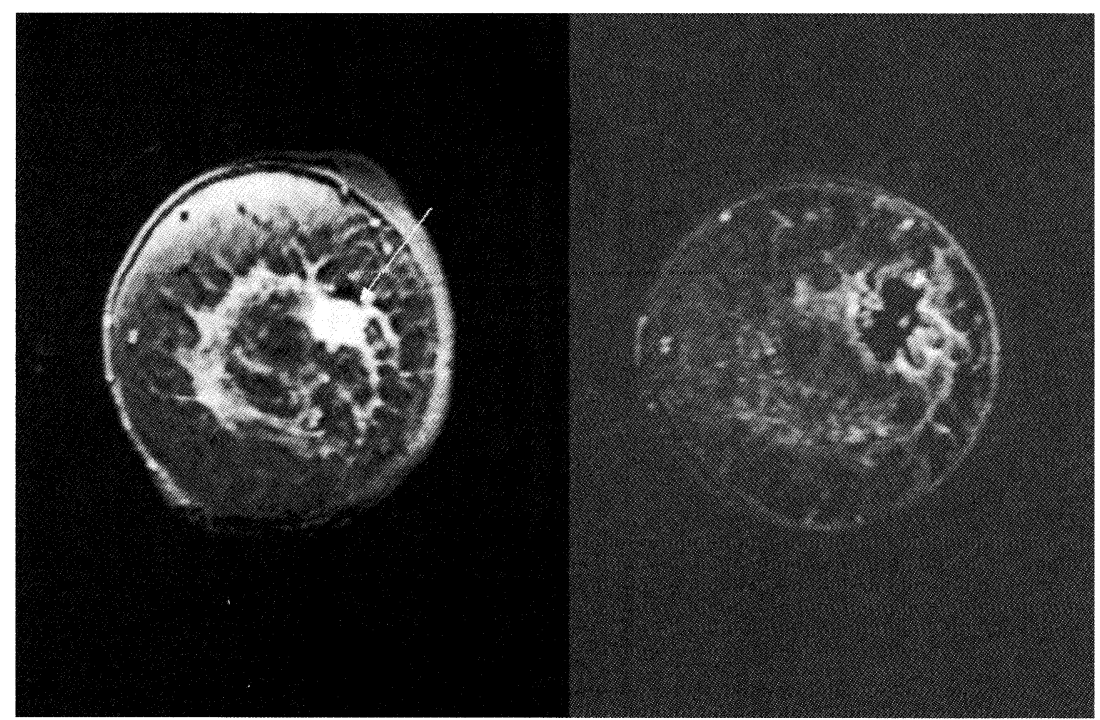

Fig. 3. Invasive breast cancer in an 82-year-old woman who was treated with MR imaging-guided FUS

A. This gadolinium-enhanced T1-weighted fast spoiled gradient-recalled-echo MR image with subtraction technique, coronal view, before FUS surgery, showed a hyperintense signal area (arrow), characteristic of breast carcinoma.

B. The posttreatment gadolinium-enhanced T1-weighted fast spoiled gradient-recalled-echo MR image with subtraction technique, coronal view, in the same patient, showed a large hypointense signal area (arrowhead) at the target. 
$\mathrm{cm}$ in diameter that are farther from the skin surface (deeper), a mean of $95.6 \% \pm 8.5 \%$ (SD) of tumor volume was within the feasible treatment radius and a mean of $88.3 \% \pm 14.0 \%$ of cancer tissue was necrosed. Residual viable cancer tissue was found outside the treatment zone in 5 patients when targeting was poor or not perfect, and residual tumor was found at the tumor periphery in 5 patients when targeting was completely accurate. In two patients, no residual cancer was found.

We have treated one patient with invasive breast carcinoma with MR imaging-guided FUS (Fig. 3A, B). Complete ablation of the invasive breast carcinoma was seen on gadolinium enhanced posttreatment MR images, however we did not obtain pathological confirmation of this result. MR image-guided FUS surgery has the potential to become an important modality for the local treatment of malignant breast tumors, in combination with radiation therapy and/or chemotherapy.

\section{Treatment of Uterine Leiomyomas}

The feasibility and safety of MR image-guided FUS surgery for symptomatic uterine leiomyomas was first described by Tempany, et al. ${ }^{17) 18}$, who reported that nonenhancing areas of uterine leiomyomas on gadolinium-enhanced posttreatment MR images were pathologically confirmed as areas of coagulative necrosis. Hindley et al. recently reported early clinical FUS results ${ }^{18)}$. In this study, $79.3 \%$ of 109 women reported a significant improvement in uterine fibroid-related symptoms on follow-up health-related quality-of-life questionnaires. The mean reduction in uterine leiomyoma volume at six months after treatment was $13.5 \%$.

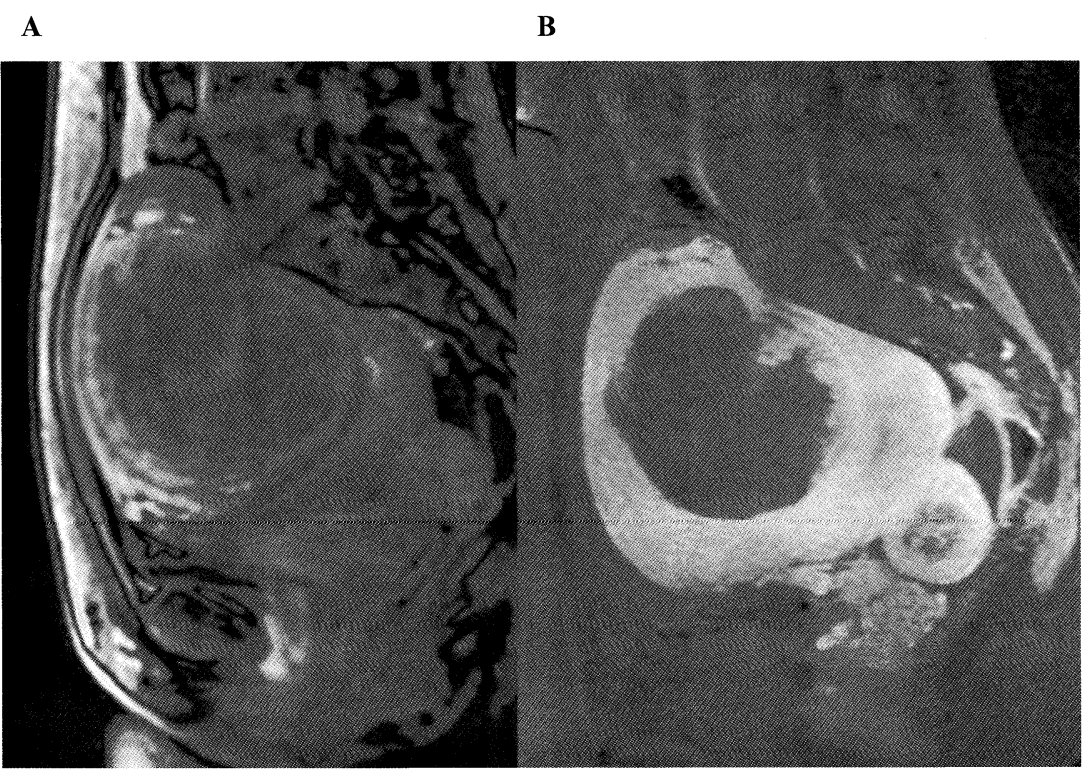

Fig. 4. A large intramural uterine leiomyoma, $10 \mathrm{~cm}$ in maximum-diameter, in a 45 year-old woman who was treated by FUS surgery

A. This gadolinium-enhanced T1-weighted fast spoiled gradient-recalled-echo MR image sagittal view, showed an intramural uterine leiomyoma, about $10 \mathrm{~cm}$ in maximum diameter, which was well enhanced before FUS surgery.

B. The posttreatment gadolinium-enhanced T1-weighted fast spoiled gradient-recalled-echo MR image, sagittal view, showed that about $60 \%$ of the total leiomyoma volume did not enhance after FUS surgery. 
We have experience treating 80 uterine leiomyoma patients with MR image-guided FUS (Fig. 4A, B). Four to $72 \%$ (mean, 38\%) of pretreatment leiomyoma volume was ablated in the larger study population. In 24 patients less than $20 \%$ of uterine leiomyoma volume was ablated. These patients did not have improvement of symptoms, and leiomyoma volume reduction three and six months after treatment was poor. Based on our experience in these patients, uterine leiomyomas that demonstrate hyperintensity relative to myometrium on T2-weighted fast SE MR images are difficult to treat with FUS. In our study, patients in whom the nonenhanced area on the posttreatment MR images was more than $50 \%$ of total leiomyoma volume had a mean leiomyoma volume reduction of almost $30 \%$ at six months after treatment, and symptom improvement was better. The only complications in these patients were a small number of mild-to-moderate skin burns. No prophylactic antibiotic treatment needed, and no infection has occurred in treated patients. MR imaging-guided FUS surgery is potentially a truly noninvasive and effective treatment for uterine leiomyomas, particularly in women who wish to avoid invasive or painful therapies.

\section{Treatment of Liver Tumor}

$\mathrm{Wu}$, et al. were first to report the safety, efficacy, and feasibility of high intensity focused ultrasound ablation for patients with hepatocellular carcinomas ${ }^{10)}$. Their procedure was performed with ultrasound guidance, under general anesthesia. While good target definition and focal spot control may be possible with ultrasound guidance in some nonanesthetized patients who are able to hold their breath for sufficient time, temperature elevation in treated tissue cannot be monitored on ultrasound images. MR imaging-guidance is necessary for greater safety and effectiveness.

MR image-guided FUS for liver tumors in humans has not yet been reported. The technical challenges currently limiting FUS in the liver include movement due to respiration, difficulty planning a beam path that avoids the ribs, and difficulty sedating patients, since general anesthesia is not easily used in the MR imaging room. Respiratory-gating techniques that compensate for liver motion are now under investigation. FUS systems require further development to create beam paths that can be designed to avoid the rib cage and overcome other limitations in the liver. MR imaging-guided FUS may be a promising method to treat malignant liver tumors as the technology evolves, especially in the patients with poor liver function or significant ascites.

\section{Treatment of Brain Tumor}

The major technical challenge for MR image-guided FUS treatment of brain tumor is distortion of the ultrasound beam as it passes through the skull, which makes accurate targeting difficult and necessitates higher energy ultrasound signals to provide a therapeutic dose in deep targets. The development of large phased arrays may enable correction of distortion, and provide adequate focused energy for trans-skull brain therapy.

MR image-guided FUS of the brain in a primate model, rhesus monkeys, has recently been examined. In this study, lethal temperature values and histologically confirmed tissue damage were confined to the focal target, except when the focus was close to the bone ${ }^{19)}$. The capabilities demonstrated in this study will be of benefit for clinical ultrasound therapy in the human brain. 


\section{Summary}

FUS surgery is well suited for safe and effective local coagulation of deep target volumes without insertion of probes and with no damage to surrounding or overlaying tissue. MR image-guided FUS provides a potentially noninvasive and effective treatment for the management of tumors in some organs. However, more clinical investigation and further device development is needed prior to routine clinical use.

\section{References}

1) Godd GD 3rd, Soulen MC, Kane RA, Livraghi T, Lees WR, Yamashita Y, Gillams AR, Karahan OI, Rhim H. : Minimally invasive treatment of malignant hepatic tumors : At the threshold of major breakthrough. Radiographics 20 : 9-27, 2000.

2) Vogl TJ, Straub R, Eichler K, Sollner O, Mack MG. : Colorectal Carcinoma Metastases in Liver: Laser-induced Interstitial Thermotherapy_Local Tumor Control Rate and Survival Data. Radiology 230: 450-458, 2004.

3) Law P, Gedroyc WM, Regan L. : Magnetic resonance guided percutaneous laser ablation of uterine fibroids. Lancet 354 : 2049-2050, 1999.

4) Sewell PE, Amola RM, Robinette C, Cowan BD. : Real time I- MR-imaging-guided cryoablation of uterine fibroids. J Vasc Interv Radiol 12: 891-893, 2001.

5) Lynn JG, Zwemer RL, Chick AJ. : A new method for the generation and use of focused ultrasound in experimental biology. J General Physiology 26 : 179-193, 1942.

6) FRY WJ, BARNARD JW, FRY FJ, BRENNAN JF. : Ultrasonically produced localized selective lesions in the central nervous system. Am J Phys Med 34 : 413-423, 1955.

7) Heimburger RF.: Ultrasound augmentation of central nervous system tumor therapy. Indiana Medicine 78 : 469-476, 1985.

8) Uchida T, Muramoto M, Kyunou H, Iwamura M, Egawa S, Koshiba K. : Clinical outcome of high intensity focused ultrasound for treating benign prostate hyperplasia : preliminary report. Urology 152: 1956-1960, 1998.

9) Gelet A, Chapelon JY, Bouvier R, Pangaud C, Lasne Y. : Local control of prostate cancer by transrectal high intensity focused ultrasound therapy: preliminary results. J Urol 161 : 156-162, 1999.

10) Wu F, Wang ZB, Chen WZ, Zhu H, Bai J, Zou JZ, Li KQ, Jin CB, Xie FL, Su HB. : Extracorporeal High Intensity Focused Ultrasound Ablation in the Treatment of Patients with Large Hepatocellular Carcinoma. Ann of Surg Oncol $11: 1061-1069,2004$.

11) Cline HE, Schenck JF, Hynynen K, Watkins RD, Souza SP, Jolesz FA. : MR-guided focused ultrasound surgery. J Comput Assist Tomogr. 16: 956-65, 1992.

12) Jolesz FA, Jakab PD.: Acoustic pressure wave generation within a MR imaging system: potential medical applications. J Magn Reson Imaging 1: 609-613, 1991.

13) Hynynen K, Darkazanli A, Unger E, Schenck JF.: MRI-guided noninvasive ultrasound surgery. Med Phys 20: 107-115, 1993.

14) Hynynen K, Freund WR, Cline HE, Chung AH, Watkins RD, Vetro JP, Jolesz FA. : A clinical noninvasive MRI monitored ultrasound surgery method. RadioGraphics 16 : 185-195, 1996.

15) Hynynen K, Pomeroy O, Smith DN, Huber PE, McDannold NJ, Kettenbach J, Baum J, Singer S, Jolesz FA. : MR imaging-guided focused ultrasound surgery of fibroadenomas in the breast: a feasibility study. Radiology 219 : 176-185, 2001.

16) Gianfelice D, Khiat A, Amara M, Belblidia A, Boulanger Y.: MR imaging-guided focused US ablation of breast cancer : histopathologic assessment of effectiveness-initial experience. Radiology $227: 849-855,2003$. 
17) Tempany CM, Stewart EA, McDannold N, Quade BJ, Jolesz FA, Hynynen K. : MR imaging-guided focused ultrasound surgery of uterine leiomyomas : a feasibility study. Radiology 226: 897-905, 2003.

18) Hindley J, Gedroyc WM, Regan L, Stewart E, Tempany C, Hynyen K, Mcdannold N, Inbar Y, Itzchak Y, Rabinovici J, Kim HS, Geschwind JF, Hesley G, Gostout B, Ehrenstein T, Hengst S, Sklair-Levy M, Shushan A, Jolesz F. : MR guidance of focused ultrasound therapy of uterine fibroids : early results. Am J Radiol 183 : 1713-1719, 2004.

19) McDannold N, Moss M, Killiany R, Rosene DL, King RL, Jolesz FA, Hynynen K. : MRI-guided focused ultrasound surgery in the brain: tests in a primate model. Magn Reson Med. 49: 1188-91, 2003.

20) Chung AH, Hynynen K, Colucci V, Oshio K, Cline HE, Jolesz FA.: Optimization of spoiled gradient-echo phase imaging for in vivo localization of focused ultrasound beam. Magn Reson Med 36: 745-752, 1996.

21) Kuroda K, Chung AH, Hynynen K, Jolesz FA. : Calibration of water proton chemical shift with temperature for noninvasive temperature imaging during focused ultrasound surgery. J Magn Reson Imaging 8: 175-181, 1998.

22) Hynynen K, Darkazanli A, Damianou CA, Unger E, Schenck JF.: The usefulness of contrast agent and GRASS imaging sequence for MRI guided noninvasive ultrasound surgery. Invest Radiol 29: 897-903, 1994.

23) Chen L, Bouley D, Yuh E, D’Arceuil H, Butts K. : Study of focused ultrasound tissue damage using MRI and histology. J Magn Reson Imaging 10 : 146-153, 1999. 


\title{
MRI ガイド下集束超音波治療
}

\author{
三上 恒 治 ${ }^{1,2}$ - 村 上卓 道 ${ }^{1}$ 岡 田 篤 哉 ${ }^{2}$ \\ 丸川太 朗 2 中 中 村 仁 信 ${ }^{1}$ \\ ${ }^{1}$ 大阪大学大学院医学系研究科 放射線統合医学講座 放射線医学講座 \\ 2医誠会病院画像応用低侵襲治療 (IVR) センター
}

要旨：集束超音波療法 (Focused Ultrasound Surgery；FUS) は, 焦点域の組織のみを壊死させる 低侵襲性熱凝固治療である.50 年前より超音波ガイドによる FUS 治療の臨床応用が報告されてきたが, 不正確な位置情報, 温度測定法の欠如, 治療効果の評価法の欠如により十分な治療成績が得られていな かった. しかしながら, MRI ガイドによる正確な位置情報の取得と治療中の温度計測により安全で正確 な治療が可能になった. また造影 MRIにより治療直後に治療効果を評価することが可能となった. 本稿 では MRI ガイド下 FUS 治療の原理, 治療方法と最近の臨床応用について述べる. 